Original Article

\title{
In vitro study of antimicrobial activity of some plant seeds against bacterial strains causing food poisoning diseases
}

\author{
Estudo in vitro da atividade antimicrobiana de algumas sementes de plantas contra \\ cepas bacterianas que causam doenças de intoxicação alimentar
}

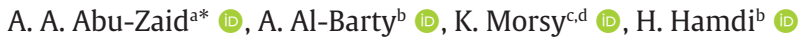 \\ aTaif University, Alkhurmah University College, Department of Biology, Taif, Saudi Arabia \\ ${ }^{\mathrm{b}}$ Taif University, College of Science, Department of Biology, Taif, Saudi Arabia \\ 'Cairo University, Faculty of Science, Zoology Department, Cairo, Egypt \\ ${ }^{d}$ King Khalid University, College of Science, Biology Department, Abha, Saudi Arabia
}

\begin{abstract}
In this research, some plant seeds powder was evaluated to find their potential effect to rule diseases of food poisoning. Antimicrobial effect of five plant seeds was examined contra Bacillus cereus, Staphylococcus aureus, Escherichia coli, Klebsiella. pneumonia and Candida albicans by using well diffusion method. Antimicrobial activity studies revealed high potential activity of plant seeds powder of Nigella sativa L., cucurbita pepo, Sesamum radiatum, Trigonella foenum-graecum, Linum usitatissimum with variable efficiency contra tested microbial strains with concentration of $100 \mathrm{mg} / \mathrm{ml}$, except Sesamum radiatum scored no effect. The T. foenum and $N$. sativa seed powder showed the largest inhibition zone (24-20 mm) contra K. pneumonia, followed by S. aureus (20-18 mm) and C. albicans $(15 \mathrm{~mm})$ respectively. The five plant seeds powder exhibited bacteriostatic and bactericidal effects with MIC's 20 and MBC $40 \mathrm{mg} / \mathrm{ml}$ against K. pneumonia, and MIC's 40 and MBC $60 \mathrm{mg} / \mathrm{ml}$ against S. aureus. The results of this study indicated that plants seeds powder have promising antimicrobial activities and their potential applications in food process. It could be utilized as a natural medicinal alternative instead of chemical substance.
\end{abstract}

Keywords: plant seed powder, antimicrobial, food poisoning, diseases.

\begin{abstract}
Resumo
Nesta pesquisa, o pó de sementes de plantas foi avaliado para encontrar seu efeito potencial no controle de doenças de intoxicação alimentar. O efeito antimicrobiano de cinco sementes de plantas foi examinado contra Bacillus cereus, Staphylococcus aureus, Escherichia coli, Klebsiella pneumonia e Candida albicans usando o método de difusão bem. Estudos de atividade antimicrobiana revelaram alto potencial de atividade de sementes de plantas em pó de Nigella sativa L., Cucurbita pepo, Sesamum radiatum, Trigonella foenum-graecum, Linum usitatissimum com eficiência variável contra cepas microbianas testadas com concentração de $100 \mathrm{mg} / \mathrm{ml}$, exceto Sesamum radiatum com pontuação não efeito. $O$ pó de sementes de $T$. foenum e $N$. sativa apresentou a maior zona de inibição (24-20 mm) contra K. pneumonia, seguido por S. aureus $(20-18 \mathrm{~mm})$ e C. albicans $(15 \mathrm{~mm})$, respectivamente. O pó de cinco sementes de plantas exibiu efeitos bacteriostáticos e bactericidas com MIC's 20 e MBC $40 \mathrm{mg} / \mathrm{ml}$ contra K. pneumonia, enquanto MIC's 40 e MBC $60 \mathrm{mg} / \mathrm{ml}$ contra S. aureus. Os resultados deste estudo indicaram que os pós de sementes de plantas apresentam promissoras atividades antimicrobianas e suas potenciais aplicações em processos alimentícios. Ele poderia ser utilizado como alternativa medicinal natural em vez de substância química.
\end{abstract}

Palavras-chave: pó de semente de planta, antimicrobiano, intoxicação alimentar, doença.

\section{Introduction}

Food poisoning disease is generally known as illness or ailment induced by the consuming food polluted with bacteria, Fungi, parasites, or toxic substance. These poisonous substances have different ways to enter food chain process (from farm to table), and make them unfit for human consumption. Centers of control disease and prevention $(C D C)$ reported that Food borne disease are causes a major problem around worldwide not especially for developing countries only, that lead to illness and death (Sapkota et al., 2012). At the United States Department of Agriculture (USDA), it is estimated that cost of foodborne illness is $\$ 15.6$ billion annually. Bacteria are recorded as the most prevalent biological hazards associate with food borne diseases. The main strains of bacteria were

*e-mail: a.zaid@tu.edu.sa

Received: September 30, 2021 - Accepted: October 08, 2021 
isolated from food products Gram negative bacteria like; Salmonella typhi, Escherichia coli and Pseudomonas aeruginosa (Pandey and Singh, 2011), and Gram-positive bacteria especially; Bacillus cereus, clostridium species, Staphylococcus aureus (Mostafa et al., 2018) Reduction of food poisoning diseases and their own agents are candidates by using of chemical preservatives (Shan et al., 2007). These chemical substances have efficiency role against outbreak control of food poisoning diseases, but used it abundant continuously lead to unpleasant side effect on human healthiness and accumulated in their bodies (Bialonska et al., 2010). Worldwide are focused on the use a natural food preservative to keep the health of human safe, regarded as nutritionally safe and easily degradable. Plant extracts are utilized as a natural source of antimicrobial agents and food pathogens. (Ogbulie et al., 2007; Berahou et al., 2007).

Several researchers explained the antimicrobial effect of plant extractors against food poisoning bacteria (Verma et al., 2012; Akinpelu et al., 2014), they are used as a source of natural component kept food from contamination with pathogenic bacteria and increase nutritive food value (Nasar-Abbas and Halkman, 2004). Antimicrobial activity of Petroleum ether and Ethanol Alkatan extracts were revealed significant inhibitory effects against Gram positive (S. aureus and B. cereus) and Gram-negative bacteria (K. pneumoniae and P. aeruginosa). The clearest activity was seen against K. pneumoniae using Petroleum ether Alkatan extract at concentration $50 \mathrm{mg} / \mathrm{cm} 3$, while ethanol Alkatan concentration $200 \mathrm{mg} / \mathrm{cm} 3$ against B. cereus (Al-Bayati, 2007). Flax seeds of Linum usitatissimum (Alkatan) has bactericidal role against $P$. gingivalis with concentricity at $100 \mu \mathrm{l} / \mathrm{ml}$, and can be applied to treatment the periodontitis therapy (Badiger et al., 2019). Raja Narender et al., (2016) suggested that the Flax seeds powder has a bacteriostatic or bactericidal and fungicidal actions.

Al-Ameedy and Omran (2019) investigated the effect of Nigella sativa purified oil fractions by solvents against tested bacterial strains. Both Hexane and chloroform Fractions showed strong antimicrobial activity against E. coli, K. pneumonia and intestinal flora with inhibition zone (IZ) ranged 18-19 $3.5 \mathrm{~mm}$ (Singh et al.,2005). Staphylococcus aureus scored a weak effect against these both fractions with (IZ 8.6 $\pm 3.3 \mathrm{~mm}$ ) (Salman et al., 2016). In addition, methicillin resistant $S$. aureus (MRSA)were sensitive to ethanolic $N$. sativa extract with concentricity $4 \mathrm{mg} / \mathrm{disc}$, while the extract had a MIC range of $0.2-0.5 \mathrm{mg} /$ $\mathrm{ml}$ (Hannan et al., 2008). Moreover, the ethyl acetate, water, and acetone fractions did not exhibit any effect against all bacterial strains. Black seeds powder recorded the lowest bactericidal concentration $47.5 \%$ contra Salmonella typhi (Utami et al., 2016). Some researchers concluded that methanolic pumpkin extract had effective inhibition active contra B.subtilis, E. coli, S. aureus, and Pseudomonas, while it was ineffective against Aspergillus niger and Candida albicans (Soni and Bali, 2019) with MIC's ranged from 20 to $60 \mathrm{mg} / \mathrm{ml}$. Moreover, Pumpkin oil had highest antibacterial efficiency with K. pneumoniae and Acinobacter baumannii, and antifungal effect versus $C$. albicans at MIC's 8 to $16 \mu \mathrm{g} / \mathrm{mL}$ (Sener et al., 2006).
The antimicrobial impact of Fenugreek leaves, seeds and stem extract by (Methanol, Acetone and water extract) against $E$. coli and S. aureus were studied by Sharma et al. (2017) The highest inhibition region with potential effectiveness against $E$. coli and S.aureus was determined by methanol in the range 20 and $19 \mathrm{~mm}$, followed by $16 \mathrm{~mm}$ by Acetone respectively, while the water extract showed without region of inhibition. Moreover, Ethanolic Fenugreek Seeds powder displayed the highest antibacterial effect contra $P$. aeruginosa and $S$. aureus with inhibition Zones (22 and $17 \mathrm{~mm}$ ) (Al-Timimi, 2019).

Black sesame seed powder showed high antimicrobial actions against major periodontal pathogens like; Fusobacterium nucleatum; Porphyromonas gingivalis; and, Prevotella intermedia (Aditya et al., 2019). HeidariSoureshjani et al. (2017) concluded that the minimum inhibitory concentration of sesame oil $32 \mathrm{mg} / \mathrm{mL}$ was effective against $S$. aureus. Rao et al. (2013) stated that the aqueous extract of sesame oil had an antimicrobial activity for K. pneumoniae, E. coli, S. aureus, P. aeruginosa, and C.albicans.

Previous studies are Focusing on the efficiency of plant extractors like; alcohol, aqueous, and oil of these plants; Nigella sativa L., Cucurbita pepo, Sesamum radiatum, Trigonella foenum-graecum, and Linum usitatissimu against food spoilage bacteria are studied in Arabian area. Therefore, the current research aims to evaluate the potential role of these plant seeds powder as an antimicrobial action against food poisonings diseases caused by S. aureus, B. cereus. E. coli, K. pneumonia and C. albicans in vitro.

\section{Materials and Methods}

\subsection{Plant seeds powder}

Five of plant seeds included in this research (Table 1) were purchased from local market of Taif, Saudi Arabia. The seeds were cleaned, disinfected, rinsed by distilled water then dried in shade. The dried plant seeds of every plant species were grounded into fine powder. The plant seeds powder was weighted, stored in a small bottle in dry place.

\subsection{Antibacterial activity of the plant seeds powder}

\subsubsection{Bacterial strains}

The own antimicrobial effect of every plant seed was assessed against four types of bacteria and one type of yeast that cause food borne diseases. Two strains of bacteria are Gram- positive such as; Bacillus cereus and Staphylococcus aureus (ATCC 25923) were isolated and identified by Abu-Zaid et al. (2016). Two strains of Gramnegative bacteria (Escherichia coli and Klebsiella pneumonia) and as well as Candida albicans (ATCC 36232) (yeast). These strains were obtained from the culture collection of Microbiology laboratories department; faculty of science Cairo University, Egypt.

\subsubsection{Inoculum's preparation}

Each strain was sub-cultured on Mueller-Hilton agar slants at $37 \circ \mathrm{C} 24$ hours. The cell harvest was used for 
Table 1. The ethnobotanical data of used plant seeds species.

\begin{tabular}{cccc}
\hline Plant species & Family & Local name & Common name \\
\hline Nigella sativa L. & Ranunculaceae & Habat albarika & Black cumin \\
Cucurbita pepo & Cucurbitaceae & Alqare & Pumpkin \\
Sesamum radiatum & Pedaliaceae & Alsamsim & Sesame \\
Trigonella foenum-graecum & Fabaceae. & Alhalba & Fenugreek \\
Linum usitatissimum & Linaceae & Alkatan & Flax(lin) \\
\hline
\end{tabular}

microbial activity contained viable cell count of $10^{7}$ colony forming units (CFU / ml) by MacFarland. Briefly, the antimicrobial activity determined by 0.5 MacFarland, the freshly inoculum was adjusted for each test by incubation the nutrient broth overnight at $37 \circ \mathrm{C}$.

\subsubsection{Antibacterial activity of plant seeds powder}

The Antimicrobial effect of all plant seeds powder assessed by well diffusion technique. Fifteen $\mathrm{ml}$ of agar media of Mueller-Hilton was poured into sterilized Petri dishes (as a basis layer), followed by each examined organism previously as microbial suspension (one hundred $\mathrm{ml}$ of media per $1 \mathrm{ml}$ of $10^{7} \mathrm{CFU}$ ), then pour $15 \mathrm{ml}$ of Mueller Hinton Agar (BD Difco) to attain $10^{5} \mathrm{CFU} / \mathrm{ml}$ of organism (as a second layer). Plant seed powder concentrates $(100 \mathrm{mg} / \mathrm{ml}$ media) loaded into the well ( $8 \mathrm{~mm}$ in diameter) was placed on the top of Mueller-Hilton agar dishes. The dishes were kept in the refrigerator at $5{ }^{\circ} \mathrm{C}$ for 2 - Hours. Filter paper disc filled with $5 \mathrm{mg}$ of Pencilline were used as a positive control. The antimicrobial vigor was assessed by calculating the diameter of the inhibition region around the well. The averages of three replicates were calculated.

\subsubsection{Evaluation of Minimum Inhibitory Concentrations (MIC's) of the effective plant seeds powder}

The minimum concentration of the antimicrobial agent which inhibits the microbial inoculum after 24 -hours of incubation period is known as MIC. Plant seeds powder with varied concentrations $(10,20,30,40,50,60,70,80,90$ and $100 \mathrm{mg} / \mathrm{ml}$ ) were filled their needful amount on the discs (diameter $8 \mathrm{~mm}$ ). The discs were loaded with different concentrations of plant seeds powder on the MuellerHilton agar media. All plates preserved in the refrigerator Two Hours at $5 \circ \mathrm{C}$ after that incubated twenty-four Hours at $37{ }^{\circ} \mathrm{C}$. The inhibition regions were calculated by the diameter of clear zone round the disc then record results versus to every concentration of the plant seeds powder. The averages of three replicates were calculated.

\subsubsection{Evaluation of Minimum Bactericidal Concentrations (MBC's) of the efficient plant seeds powder}

The discs are taken from the two minimum concentrations of the plant seeds powder dishes showed no growth (from clear inhibition region of MIC dishes), then inoculates under aseptic conditions on sterilized plate of Tryptone soya agar (TSA). The Dishes were kept in the incubator for 24-Hours at $37{ }^{\circ} \mathrm{C}$. then microbial growth was examined with the equivalent to plant seed powder concentration. The concentration of plant seeds powder did not show any bacterial growth on the freshly inoculated tryptone soy agar was recorded as MBC.

\subsection{Statistical analysis}

The diameter of inhibition zone data was analyzed by SAS program using one way ANOVA. The results were expressed as mean $( \pm \mathrm{SD})$. The data at $p<.05$ were considered significant.

\section{Results}

\subsection{Antimicrobial activity}

Table 2 and Figure 1 showed the effect of plant seeds powder against microbial strains including; Gram ve $e^{+}$bacteria (B. cereus, S. aureus), Gram ve-bacteria (E. coli, K. pneumonia), and C.albicans. S. radiatum seeds showed no effect against all examined strains. However, other plant seeds exhibited different inhibitory effect for both gram positive, gramnegative bacteria and yeast. T. foenum exhibited the most inhibitory effect against five microbial growth (B. cereus, S. aureus, C.albicans, E. coli E K. pneumonia) at concentration of $100 \mathrm{mg} / \mathrm{ml}$, Followed by N. sativa , and L. usitatissimum seeds. Whereas, Cucurbita pepo seeds was effective against four of them (S. aureus, K. pneumonia, c. albicanse E'E. coli). The most sensitive strain was K. pneumonia against seed plants followed by S. aureus, C. albicans, while E. coli and were the most resistance strains to the plant seeds respectively. The highest inhibition zone of $T$. foenum (24 mm) and $N$. sativa seed $(24 \mathrm{~mm}$ ) as comparable with the positive control, Pencilline (10 mm), against K. pneumonia. While, The lowest inhibition zone of $C$. pepo seeds powder $7 \mathrm{~mm}$, $10 \mathrm{~mm}$, and $12 \mathrm{~mm}$ against E. coli, S. aureus and K. pneumonia respectively as comparable with the positive control.

\subsection{Minimum Inhibitory Concentrations (MIC's) of the effect of plant seeds powder}

The MIC of the most potent plant powder ( $T$. foenum and $N$. sativa seed) were examined by method of well diffusion to estimate their bacteriostatic and bactericidal activates. Table 3 and Figure 2 revealed that the minimum inhibitory effect of $T$. foenum and $N$. sativa $L$. seeds were at $20 \mathrm{mg} / \mathrm{ml}$ with inhibition zones of 8.9 and $7.5 \mathrm{~mm}$ against K. pneumonia, while these plant seeds powder at $40 \mathrm{mg} / \mathrm{ml}$ concentration of inhibited bacterial growth of $S$. aureus with inhibition zones of 9.3 and $7.4 \mathrm{~mm}$ respectively. 
Table 2. Antimicrobial activities of some plant seeds powder against some microbial strains of food poisoning diseases.

\begin{tabular}{|c|c|c|c|c|c|}
\hline \multirow{3}{*}{ Plant seeds Species } & \multicolumn{5}{|c|}{ Inhibition Zone (mm) } \\
\hline & \multicolumn{2}{|c|}{ Gram Negative Bacteria } & \multicolumn{2}{|c|}{ Gram Positive Bacteria } & \multirow{2}{*}{$\begin{array}{c}\text { yeast } \\
\text { C.albicans }\end{array}$} \\
\hline & E. coli & K. pneumina & B. cereus & S. aureus & \\
\hline Nigella sativa $L$. & $15.3 \pm 0.57$ & $20.5 \pm 0.57$ & $13.1 \pm 0.32$ & $18.6 \pm 0.56$ & $15.2 \pm 0.11$ \\
\hline Cucurbita pepo & $7.0 \pm 0.44$ & $12.6 \pm 0.54$ & $0.0 \pm 0.0$ & $10.4 \pm 0.48$ & $10.3 \pm 0.37$ \\
\hline Sesamum radiatum & $0.0 \pm 0.0$ & $0.0 \pm 0.0$ & $0.0 \pm 0.0$ & $0.0 \pm 0.0$ & $0.0 \pm 0.0$ \\
\hline Trigonella foenum-graecum & $15.8 \pm 0.45$ & $24.5 \pm 0.53$ & $13.7 \pm 0.55$ & $20.6 \pm 0.57$ & $15.6 \pm 0.59$ \\
\hline Linum usitatissimum & $12.4 \pm 0.32$ & $15.2 \pm 0.33$ & $10.4 \pm 0.50$ & $13.2 \pm 0.43$ & $13.2 \pm 0.31$ \\
\hline Pencillin (5 mg) & $0.0 \pm 0.0$ & $10.1 \pm 0.22$ & $0.0 \pm 0.0$ & $0.0 \pm 0.0$ & $0.0 \pm 0.0$ \\
\hline
\end{tabular}

Data are means of three replicates $(n=3) \pm S D$.

Table 3. Minimum Inhibition Concentration of the most effective plant seeds powder against S. aureus and K. pneumina.

\begin{tabular}{|c|c|c|c|}
\hline \multirow{3}{*}{ Plant Seeds Species } & \multirow{3}{*}{ Conc. $\mathrm{mg} / \mathrm{ml}$} & \multicolumn{2}{|c|}{ Inhibition Zone (mm) } \\
\hline & & Gram-Negative Bacteria & Gram-Positive Bacteria \\
\hline & & K. pneumina & S. aureus \\
\hline \multirow[t]{9}{*}{ Trigonella foenum-graecum } & 10.0 & $0.0 \pm 0.0$ & $0.0 \pm 0.0$ \\
\hline & 20.0 & $8.9 \pm 0.56$ & $0.0 \pm 0.0$ \\
\hline & 30.0 & $12.6 \pm 0.58$ & $0.0 \pm 0.0$ \\
\hline & 40.0 & $15.8 \pm 0.49$ & $9.3 \pm 0.42$ \\
\hline & 50.0 & $17.5 \pm 0.40$ & $12.5 \pm 0.48$ \\
\hline & 60.0 & $19.8 \pm 0.39$ & $15.8 \pm 0.42$ \\
\hline & 70.0 & $20.2 \pm 0.45$ & $17.2 \pm 0.50$ \\
\hline & 80.0 & $22.7 \pm 0.38$ & $21.7 \pm 0.24$ \\
\hline & 100.0 & $25.3 \pm 0.58$ & $22.7 \pm 0.56$ \\
\hline \multirow[t]{9}{*}{ Nigella sativa $L$. } & 10.0 & $0.0 \pm 0.0$ & $0.0 \pm 0.0$ \\
\hline & 20.0 & $7.5 \pm 0.0$ & $0.0 \pm 0.0$ \\
\hline & 30.0 & $8.6 .0 \pm 0.0$ & $0.0 \pm 0.0$ \\
\hline & 40.0 & $10.8 \pm 0.36$ & $7.4 .0 \pm 0.43$ \\
\hline & 50.0 & $12.5 \pm 0.59$ & $15.0 \pm 0.67$ \\
\hline & 60.0 & $15.8 \pm 0.57$ & $18.8 \pm 0.54$ \\
\hline & 70.0 & $18.2 \pm 0.43$ & $20.2 \pm 0.23$ \\
\hline & 80.0 & $19.7 \pm 0.48$ & $22.7 \pm 0.38$ \\
\hline & 100.0 & $21.7 \pm 0.24$ & $20.7 \pm 0.35$ \\
\hline
\end{tabular}

Data are means of three replicates $(n=3) \pm S D$.
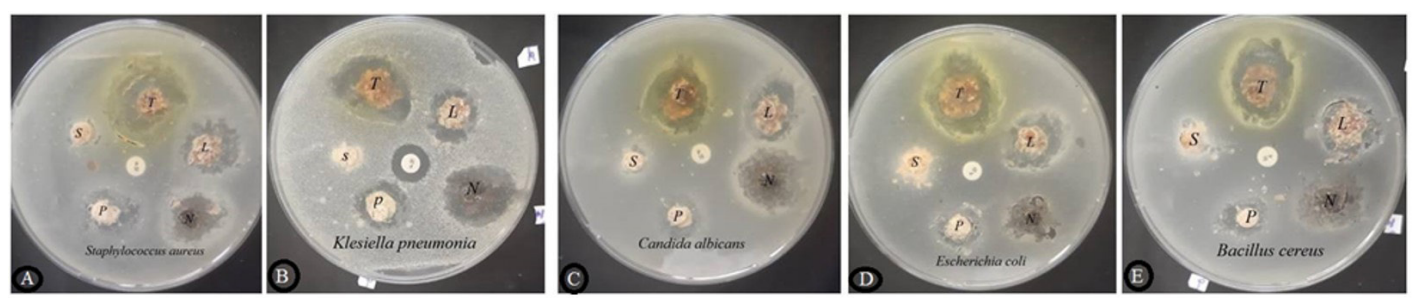

Figure 1. Growth inhibition of some food poisoning microbial strains caused by plant seeds powder. N, Nigella sativa; P, Cucurbita pepo; $S$, Sesamum radiatum; T, Trigonella foenum-graecum; $L$, Linum usitatissimum and $+C$, positive control. 


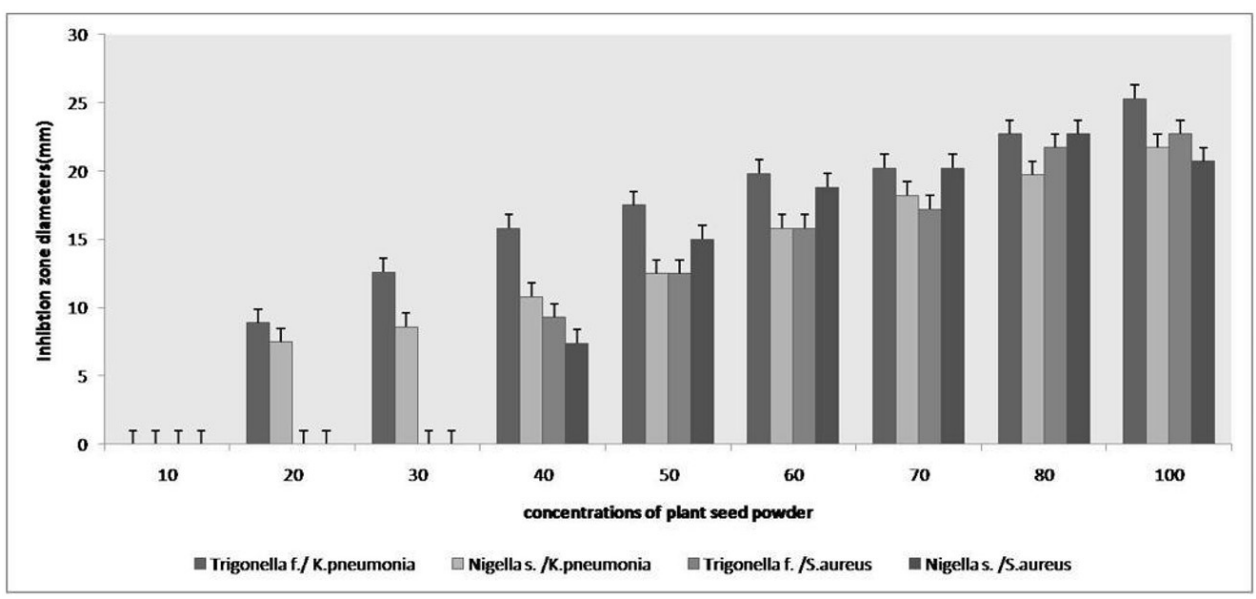

Figure 2. MIC's of the effective plant seeds powder against S. aureus and K. pneumonia, \pm standard error.

\subsection{Minimum Bactericidal Concentrations (MBC's) of the most effective plant seeds powder}

The MBC was confirmed from the absence of bacterial growth of the examined strains-streaked form the lowest MIC's. T. foenum and N. sativa seeds exhibited bactericidal activity against K.pneumonia with MBC $6 \mathrm{mg} / \mathrm{ml}$, while $\mathrm{MBC}$ of these plant seeds against $S$. aureus were $80 \mathrm{mg}$ / $\mathrm{ml}$. From these results $T$. foenum and $N$. sativa seeds were scored lowest concentration from MIC and MBC against K.pneumonia, followed by S. aureus. These plant seeds can be used to decrease or prevent food borne bacteria and food poisoning diseases. These strains of Bacteria used in this work caused a major problem in food, which were a source of food spoilage and food poisoning. MIC and MBC results of the potent plant seeds powder indicated that $T$. foenum and $N$. sativa seeds can be utilized to rule and prohibit bacteria of food borne, prevent bacterial toxins and food poisoning diseases. Whereas, B. cereus, E. coli, $S$. aureus and K.pneumonia the main cause of food borne disease ,because they produce toxins and other metabolites that cause human intestinal diseases. At the present data K.pneumonia was the most sensitive bacteria suppressing by plant seeds (T. foenum and $N$. sativa) and scored lowest MIC at $20 \mathrm{mg} / \mathrm{ml}$.

\section{Discussion}

The difference in resistance of Gram $v e^{+}$bacteria as $S$. aureus, B. cereus and Gram ve-bacteria as K.pneumonia , E. coli to plant seeds powder, it could be related to differences in the cell membranes. These results are in the same line with those reported by (Kim et al., 2011). The selective barrier outer membrane Gram ve -bacteria are hydrophilic molecules, the ion channel of this bacteria is very small to allow internalization of the plant seeds, while Gram $v e^{+}$ bacteria have a thick peptido-glycan layer that contains teichoic and lipoteichoic acid (Amato et al., 2011).

Our study revealed that Plant seeds had antimicrobial activity on the food poisoning bacteria and with varied inhibition zone. Variation in MIC of all plant seeds were used may increase according to chemical constituents and volatile nature. These results are in accordance with (Badiger et al., 2019; Soni and Bali, 2019; Sharma et al., 2017).

Zone inhibition of $T$. foenum seeds were found at (100 mg/ml) concentration against B. cereus, S. aureus, E. coli, C. albicans and K.pneumonia suppressing their growth with zones ranged from $13-24 \mathrm{~mm}$. These results were in agreement with Sharma et al. (2017) and Thomas et al. (2011). $N$. sativa scored inhibition zone range $13-20 \mathrm{~mm}$ and MIC from 20 to $40 \mathrm{mg} / \mathrm{ml}$ against K.pneumonia and S. aureus . Our results are in the same line of Sheikh et al. (2010) and (Dua et al., 2013) who revealed that the potentially effect of these plant seeds with MIC range (6.25 to $12.5 \mathrm{mg} / \mathrm{ml}$. (Dixit et al., 2005; Halliwell, 1995) were confirmed the competency of plant seeds as antimicrobial agents due to their effective natural components to control growth of food poisoning bacteria and spoilage. These components were suggested by researchers like; (terpenoid, alkaloid, isoflavones, antioxidant and phenolic compounds), which may inhibit enzymes necessary for amino acids biosynthesis or interact with enzymes and proteins of the microbial cell membrane causing inactivation of protons in the direction outside the cell led to cell death (Burt, 2004; Gill and Holley, 2006). Badiger et al. (2019) reported that hull lignans of flaxseed have anti-microbial activity against the bacterial species. Other studies attributed the inhibitory effect of these plant extracts to their hydrophobicity characters which enable them to interact with microbial cell membrane and mitochondrial that disturb their structures and alter their permeability (Friedman et al., 2004; Tiwari et al., 2009).

\section{Conclusion}

The present study suggested that plant seeds powder which proved to be potentially effective can be used as natural preservatives to control food poisoning diseases and preserve food avoiding application of health hazards of chemical preservatives. 


\section{Declaration of conflict of interest}

None.

\section{Acknowledgements}

The authors extend their appreciation to the deanship of scientific research for funding this article by Taif University Researchers Supporting Project number (TURSP-2020/203), Taif University, Taif, Saudi Arabia.

\section{References}

ABU-ZAID, A.A., 2016. Antibacterial effect of green synthesis silver nanoparticles against Escherichia coli. Research Journal of Fisheries and Hydrobiology, vol. 11, no. 9, pp. 7-14.

ADITYA, V., BABITHA, G.A., PRAKASH, S. and TIMMASETTY, J., 2019. Evaluation of antibacterial efficacy of sesame seed on periodontal pathogens: an in vitro study. CODS Journal of Dentistry, vol. 11, no. 2, pp. 44-47.

AKINPELU, D.A., AIYEGORO, O.A., AKINPELU, O.F. and OKOH, A.I., 2014. Stem bark extract and fraction of Persea americana (Mill) exhibits bactericidal activities against strains of Bacillus cereus associated with food poisoning. Molecules (Basel, Switzerland), vol. 20, no. 1, pp. 416-429. http://dx.doi.org/10.3390/ molecules20010416. PMid:25558854.

AL-AMEEDY, T.H. and OMRAN, R., 2019. Antimicrobial activity of Nigella Sativa extract against some bacterial and fungal species. Journal of University of Babylon for Pure and Applied Sciences, vol. 27, no. 1, pp. 277-286.

AL-BAYATI, F.A., 2007. Antibacterial activity of linum usitatissimum L seeds and active compound detection. Rafidain Journal of Science, vol. 18, no. 2, pp. 27-36.

AL-TIMIMI, L.A.N., 2019. Antibacterial and anticancer activities of Fenugreek seed extract. Asian Pacific Journal of Cancer Prevention, vol. 20, no. 12, pp. 3771-3776. http://dx.doi.org/10.31557/ APJCP.2019.20.12.3771. PMid:31870120.

AMATO, E., DIAZ-FERNANDEZ, Y., TAGLIETTI, A., PALLAVICINI, P., PASOTTI, L., CUCCA, L., MILANESE, C., GRISOLI, P., DACARRO, C., FERNANDEZ-HECHAVARRIA, J.M. and NECCHI, V., 2011. Synthesis, characterization and antibacterial activity against gram positive and gram-negative bacteria of biomimetically coated silver nanoparticles. Langmuir, vol. 27, no. 15, pp. 91659173. http://dx.doi.org/10.1021/la201200r. PMid:21736306.

BADIGER, A.B., GOWDA, T.M., RAJARAJESHWARI, S., MAJHI, S.S., KUMAR, T. and MEHTA, D.S., 2019. Antimicrobial effect of flaxseed (Linum usitatissimum) on periodontal pathogens: an in vitro study. International Journal of Herbal Medicine., vol. 7, no. 3, pp. 16-19.

BERAHOU, A., AUHMANI, A., FDIL, N., BENHARREF, A., JANA, M. and GADHI, C.A., 2007. Antibacterial activity of Quercus ilex bark's extracts. Journal of Ethnopharmacology, vol. 112, no. 3, pp. 426-429. http://dx.doi.org/10.1016/j.jep.2007.03.032. PMid:17513077.

BIALONSKA, D., RAMNANI, P., KASIMSETTY, S.G., MUNTHA, K.R., GIBSON, G.R. and FERREIRA, D., 2010. The influence of pomegranate by-product and punicalagins on selected groups of human intestinal microbiota. International Journal of Food Microbiology, vol. 140, no. 2-3, pp. 175-182. http://dx.doi. org/10.1016/j.ijfoodmicro.2010.03.038. PMid:20452076.

BURT, S., 2004. Essential oils: their antibacterial properties and potential applications in foods--a review. International Journal of Food Microbiology, vol. 94, no. 3, pp. 223-253. http://dx.doi. org/10.1016/j.jfoodmicro.2004.03.022. PMid:15246235.

DIXIT, P., GHASKADBI, S., MOHAN, H. and DEVASAGAYAM, T.P., 2005. Antioxidant properties of germinated fenugreek seeds. Phytotherapy Research, vol. 19, no. 11, pp. 977-983. http://dx.doi. org/10.1002/ptr.1769. PMid:16317656.

DUA, A., GAURAV, G., BALKAR, S. and MAHAJAN, R., 2013. Antimicrobial properties of methanolic extract of cumin (Cuminum cyminum) seeds. International Journal of Research in Ayurveda and Pharmacy, vol. 4, no. 1, pp. 104-107.http://dx.doi. org/10.7897/2277-4343.04136.

FRIEDMAN, M., HENIKA, P.R., LEVIN, C.E. and MANDRELL, R.E., 2004. Antibacterial activities of plant essential oils and their components against Escherichia coli 0157:H7 and Salmonella enterica in apple juice. Journal of Agricultural and Food Chemistry, vol. 52, no. 19, pp. 6042-6048. http://dx.doi.org/10.1021/ jf0495340. PMid:15366861.

GILL, A.O. and HOLLEY, R.A., 2006. Disruption of Escherichia coli, Listeria monocytogenes and Lactobacillus sakei cellular membranes by plant oil aromatics. International Journal of Food Microbiology, vol. 108, no. 1, pp. 1-9. http://dx.doi.org/10.1016/j. ijfoodmicro.2005.10.009. PMid:16417936.

HALLIWELL, B., 1995. How to characterize an antioxidant: an update. Biochemical Society Symposium, vol. 61, pp. 73-101. http://dx.doi. org/10.1042/bss0610073. PMid:8660405.

HANNAN, A., SALEEM, S., CHAUDHARY, S., BARKAAT, M. and ARSHAD, M.U., 2008. Anti bacterial activity of Nigella sativa against clinical isolates of methicillin resistant Staphylococcus aureus. Journal of Ayub Medical College, vol. 20, no. 3, pp. 72-74. PMid: 19610522.

HEIDARI-SOURESHJANI, R., OBEIDAVI, Z., REISI-VANANI, V., DEHKORDI, S.E., FATTAHIAN, N. and GHOLIPOUR, A., 2017. Evaluation of antibacterial effect of sesame oil, olive oil and their synergism on Staphylococcus aureus in vitro. Advanced Herbal Medicine, vol. 3, no. 3, pp. 13-19.

KIM, S.-H., LEE, H., RYU, D., CHOI, S. and LEE, D., 2011. Antibacterial activity of silver-nanoparticles against Staphylococcus aureus and Escherichia coli. Microbiology and Biotechnology Letters, vol. 39, no. 1, pp. 77-85.

MOSTAFA, A.A., AL-ASKAR, A., ALMAARY, K.S., DAWOUD, T.M., SHOLKAMY, E.N. and BAKRI, M.M., 2018. Antimicrobial activity of some plant extracts against bacterial strains causing food poisoning diseases. Saudi Journal of Biological Sciences, vol. 25, no. 2, pp.361-366. http://dx.doi.org/10.1016/j.sjbs.2017.02.004. PMid:29472791.

NASAR-ABBAS, S.M. and HALKMAN, A.K., 2004. Antimicrobial effect of water extract of sumac (Rhus coriaria $L$.) on the growth of some food borne bacteria including pathogens. International Journal of Food Microbiology, vol. 97, no. 1, pp. 63-69. http:// dx.doi.org/10.1016/j.jifoodmicro.2004.04.009 PMid:15527919.

OGBULIE, J.N., OGUEKE, C.C., OKOLI, I.C. and ANYANWU, B.N., 2007. Antibacterial activities and toxicological potentials of crude ethanolic extracts of Euphorbia hirta. African Journal of Biotechnology, vol. 6, no. 13, pp. 1544-1548.

PANDEY, A. and SINGH, P., 2011. Antibacterial activity of Syzygium aromaticum (Clove) with metal ion effect against food borne pathogens. Asian J. Plant Sci. Res., vol. 1, no. 2, pp. 69-80.

RAJA NARENDER, B., TEJASWINI, S., SARIKA, M., KARUNA, N., SHIRISHA, R. and PRIYANKA, S., 2016. Antibacterial and antifungal activities of Linum Usitatissimum (Flax seeds). International Journal of Pharmacy Education and Research., vol. 3, no. 2, pp. 4-8. 
RAO, A.S., RASHMI, K.S., NAYANATARA, A.K., KISMAT, A., POOJARY, D. and PAI, S.R., 2013. Effect of antibacterial and antifungal activities of Sesamum indicum. World Journal of Pharmaceutical Research, vol. 2, no. 5, pp. 1676-1680.

SALMAN, M.T., KHAN, R.A. and SHUKLA, I., 2016. Antibacterial activity of Nigella Sativa Linn. seeds against multiple antibiotics resistant clinical strains of Staphylococcus aureus. International Archives of BioMedical and Clinical Research, vol. 2, no. 3, pp. 96-99. http://dx.doi.org/10.21276/iabcr.2016.2.3.24.

SAPKOTA, R., DASGUPTA, R. and RAWAT, D.S., 2012. Antibacterial effects of plants extracts on human microbial pathogens \& microbial limit tests. International Journal of Research in Pharmacy and Chemistry, vol. 2, no. 4, pp. 926-936.

SENER, B., ORHAN, I., OZCELIK, B., KARTAL, M., ASLAN, S. and OZBILEN, G., 2006. Antimicrobial and antiviral activities of two seed oil samples of Cucurbita pepo L. and their fatty acid analysis. Natural Product Communications, vol. 2, no. 4, pp. 1934578X0700200. http://dx.doi.org/10.1177/1934578X0700200409.

SHAN, B., CAI, Y., BROOKS, J.D. and CORKE, H., 2007. The in vitro antibacterial activity of dietary spice and medicinal herb extracts. International Journal of Food Microbiology, vol. 117, no. 1, pp. 112-119. http://dx.doi.org/10.1016/j.jffoodmicro.2007.03.003.PMid:17449125.

SHARMA, V., SIGHN, P. and RANI, A., 2017. Antimicrobial Activity of Trigonella foenum-graecum L. (Fenugreek). European Journal of Experimental Biology, vol. 7, no. 1, pp. 4. http://dx.doi. org/10.21767/2248-9215.100004.

SHEIKH, M.I., ISLAM, S., RAHMAN, A., RAHMAN, M., RAHMAN, M, RAHMAN, M, RAHIM, A. and ALAM, F., 2010. Control of some human pathogenic bacteria by seed extracts of cumin (Cuminum cyminum L.). Agriculturae Conspectus Scientificus, vol. 75, pp. 39-44.
SINGH, G., MARIMUTHU, P., HELUANI, C.S. and CATALAN, C., 2005. Chemical constituents and antimicrobial and antioxidant potentials of essential oil and acetone extract of Nigella sativa seeds. Journal of the Science of Food and Agriculture, vol. 85, no. 13, pp. 2297-2306. http://dx.doi.org/10.1002/jsfa.2255.

SONI, R.R. and BALI, M., 2019. Evaluation of antioxidant, antimicrobial, and antifungal potential of cucurbita pepo var. Fastigata seed extracts. Asian Journal of Pharmaceutical and Clinical Research, vol. 12, no. 2, pp. 289-293. http://dx.doi. org/10.22159/ajpcr.2019.v12i2.28040.

THOMAS, J.E., BANDARA, M., LEE, E.L., DRIEDGER, D. and ACHARYA, S., 2011. Biochemical monitoring in fenugreek to develop functional food and medicinal plants variants. New Biotechnology, vol. 28, no. 2, pp. 110-117. http://dx.doi.org/10.1016/j.nbt.2010.09.001. PMid:20851781.

TIWARI, B.K., VALDRAMIDIS, V.P., O' DONNELL, C.P., MUTHUKUMARAPPAN, K., BOURKE, P. and CULLEN, P.J., 2009. Application of natural antimicrobials for food preservation. Journal of Agricultural and Food Chemistry, vol. 57, no. 14, pp. 5987-6000. http://dx.doi.org/10.1021/jf900668n. PMid: 19548681.

UTAMI, A.T., PRATOMO, B. and NOORHAMDANI., 2016. Study of antimicrobial activity of black cumin seeds (Nigella sativa L.) against salmonella typhi in vitro. Journal of Medical \& Surgical Pathology, vol. 1, no. 3, pp. 1-4. http://dx.doi.org/10.4172/24724971.1000127.

VERMA, V., SINGH, R., TIWARI, R.K., SRIVASTAVA, N. and VERMA, S., 2012. Antibacterial activity of extracts of Citrus, Allium and Punica against food borne spoilage. Asian Journal of Plant Science and Research, vol. 2, no. 4, pp. 503-509. 